\title{
In vitro inhibitory effect of SR 27417, a potent platelet-activating factor (PAF) receptor antagonist, on the PAF-induced bovine platelet aggregation
}

\author{
Miriam Bastos da Silva ${ }^{\mathrm{a}}$, Annie Delaunois ${ }^{\mathrm{b}}$, Pascal Gustin ${ }^{\mathrm{b}}$, \\ Jean-Marie GODEAU ${ }^{\mathrm{c}}$, Pierre LEKEUX ${ }^{\text {a* }}$ \\ ${ }^{a}$ Laboratoire d'investigation fonctionnelle, Département de physiologie, Bât. B42, \\ Faculté de Médecine Vétérinaire, Université de Liège, Sart Tilman, 4000 Liège, Belgium \\ ${ }^{\mathrm{b}}$ Laboratoire de pharmacologie et toxicologie, Bât. B41, Faculté de Médecine Vétérinaire, \\ Université de Liège, Sart Tilman, 4000 Liège, Belgium \\ ${ }^{\mathrm{c}}$ Laboratoire de biologie clinique, Bât. B42, Faculté de Médecine Vétérinaire, \\ Université de Liège, Sart Tilman, 4000 Liège, Belgium
}

(Received 30 July 1999; accepted 10 December 1999)

\begin{abstract}
The in vitro inhibitory effect of SR 27417, an antagonist of the platelet-activating factor (PAF) receptor, on PAF-induced platelet aggregation was studied in blood collected from seven healthy Friesien calves. Inhibitory effects of SR 27417 were determined at thirteen different concentrations $(0.1-400 \mathrm{nM})$ by using the dose-response curves of PAF on calf platelet aggregation. In the presence of SR 27417, the maximal slopes of aggregation $(\% / \mathrm{min})$ induced by low and high concentrations of PAF were significantly different from the control values obtained without an antagonist at $p \leq 0.05$ and $p \leq 0.01$ respectively. In vitro PAF-induced calf platelet aggregation was dosedependently inhibited by SR 27417. The drug inhibited PAF-induced platelet aggregation in a competitive reversible manner $\left(\mathrm{pA}_{2}=10.46 \pm 2.36 \mathrm{~mol} \cdot \mathrm{L}^{-1}\right)$. In conclusion, the results of our study showed that addition of SR 27417 to bovine platelet in vitro inhibits PAF-induced platelet aggregation.

bovine / platelet / platelet aggregation / platelet-activating factor (PAF) / SR 27417
\end{abstract}

Résumé - Effet inhibiteur in vitro du SR 27417, un puissant antagoniste du récepteur du facteur d'activation plaquettaire sur l'agrégation des plaquettes induite par le PAF chez le bovin. L'effet inhibiteur in vitro du SR 27417, un antagoniste du récepteur du facteur d'activation plaquettaire (PAF) induite par le PAF sur l'agrégation plaquettaire a été étudiée dans le sang prélevé des sept veaux sains de race Frisonne. L'effet inhibiteur du SR 27417 a été déterminé avec treize concentrations différentes $(0,1-400 \mathrm{nM})$ en utilisant les courbes dose-effet du PAF sur l'agrégation

* Correspondence and reprints

Tel.: (32) 436640 30, (32) 436640 31; fax (32) 436629 35; e-mail: pierre.lekeux@ulg.ac.be 
plaquettaire des veaux. En présence du SR 27417, la pente d'agrégation maximale de la courbe (\%/min) induite par de faibles et fortes concentrations du PAF ont été significativement différentes des valeurs de base ( $p \leq 0.05$ et $p \leq 0.01$ respectivement). L'agrégation des plaquettes induites par le PAF a été inhibée in vitro par le SR 27417 d'une manière dépendante de la dose. Le médicament a inhibé in vitro l'agrégation induite par le PAF des plaquettes chez le bovin de façon compétitive et réversible $\left(\mathrm{pA}_{2}=10.46 \pm 2.36 \mathrm{~mol} \cdot \mathrm{L}^{-1}\right)$. En conclusion, les résultats de notre étude montrent in vitro que l'addition du SR 27417 aux plaquettes chez le bovin inhibe l'agrégation plaquettaire induite par le PAF.

bovin / plaquette / agrégation plaquettaire / facteur d'activation plaquettaire (PAF) / SR 27417

\section{INTRODUCTION}

It is recognised that the platelet-activating factor (PAF), an ether phospholipid, is considered as one of the most potent inducers of platelet aggregation, inducing shape change and degranulation of platelets in calves $[2,3$, $8]$ and in other animal species [11, 15, 17, 36]. As predicted, bovine platelets are very sensitive to PAF when this mediator is added in platelet-rich plasma [2-5]. Recently, a report showed that the morphological ultrastructure of blood platelets in bovines are modified following PAF infusion [4]. PAF serves as an autacoid in a wide range of physiological and pathological processes [11]. The key determinant controlling whether it serves a haemostatic or detrimental function may be the circumstances under which PAF or related compounds are generated $[1,11,16,18,19,32,36]$. In addition, Chignard et al. [15] defined a possible role for PAF in bovine inflammatory diseases. Moreover, PAF is believed to be involved in acute allergic responses, asthma, anaphylactic and septic shock $[11,18,21$, 29]. Since this mediator may also play an important role in respiratory diseases in cattle and in various other species $[1,24,25$, $27,38]$, the development of specific plateletactivating factor receptor antagonists which can inhibit PAF receptor binding is therefore essential in order to elucidate the pathophysiological roles of PAF and to develop new drugs active in various situations where PAF is believed to be involved.

The determination of the inhibition of PAF-induced platelet aggregation has been proposed as a biological standardization method for commercially available drugs $[2-4,8,10,13,19,30]$. Based on this model, a large number of PAF antagonists has been identified in the past few years. These substances include structural analogues of PAF and compounds chemically unrelated to PAF [2, 10, 12, 21, 31, 35, 37]. The structure of SR 27417 (fumarate salt) N-(2-dimethylamino ethyl)-N-(3-pyridinylmethyl) [4-(2,4,6-triisopropylphenyl)-thiazol-2-yl] amine [6, 18, 22-24], belonging to a newly developed series of PAF antagonists, has been described as being one of the most potent PAF receptor antagonist known to date when compared with other PAF antagonists [22]. These data were obtained on human, guinea pig, rat and rabbit platelets $[23,24]$. However, no such data were obtained for cattle.

Therefore, the purpose of this study was to assess in vitro influence of SR 27417 on the dose-response curve of PAF on platelet aggregation in normal calf blood.

\section{MATERIALS AND METHODS}

\subsection{Drugs}

C16:00 PAF (1- $O$-hexadecyl-2-acetylsn-glyceryl-3-phosphocholine) (99\% pure as controlled by HPLC) was obtained from Bachem Feinchemikalien AG (Bubendorf, Switzerland) and stored as stock solution $\left(1 \mathrm{mg} \cdot \mathrm{mL}^{-1}\right)$ in Ethanol at $-20{ }^{\circ} \mathrm{C}$. Serial dilutions were prepared in phosphat buffered saline (PBS, PO4 buffer $0.05 \mathrm{~mol} \cdot \mathrm{L}^{-1}$ $\mathrm{NaCl} 0.85 \%$ ) containing $0.25 \%$ bovine 
serum albumin (BSA) for platelet studies. The SR 27417 (fumarate salt) N-(2-dimethylamino ethyl)-N-(3-pyridinylmethyl) [4-(2,4,6-triisopropylphenyl)-thiazol-2-yl] amine was supplied by Sanofi Recherche (S.R.) (Toulouse, France). SR 27417 was dissolved on the day of the experiment in saline ( $\mathrm{NaCl} 0.9 \%$ solution). The diluted solutions of PAF and SR 27417 were discarded each day.

\subsection{Animals}

Seven healthy Friesien calves, weighing $100 \pm 10 \mathrm{~kg}$, were used as experimental animals for the collection of fresh blood.

\subsection{Calf platelet aggregation}

Blood samples $(50 \mathrm{~mL})$ were collected by puncture of the jugular vein in $5 \mathrm{~mL}$ "vacutainer" tubes (containing $0.5 \mathrm{~mL}$ of $3.8 \%$ trisodium citrate). The aggregation was assessed following the BORN method [9]. Platelet-rich plasma (PRP) and plateletpoor plasma (PPP) were prepared as previously described [2]. PRP was prepared from citrated venous blood by centrifugation at $270 \times g$ for $20 \mathrm{~min}$ at $100{ }^{\circ} \mathrm{C}$ and then by collecting the upper two-thirds of the plasma with a plastic pipette. PPP was obtained by recentrifuging the remaining blood at $4350 \times g$ for $15 \mathrm{~min}$ at $10^{\circ} \mathrm{C}$. The final suspension of PRP was adjusted to contain 300000 platelets per $\mu \mathrm{L}$ with homologous PPP. PRP was incubated in aliquots of $1 \mathrm{~mL}$ at $37^{\circ} \mathrm{C}$ for $1 \mathrm{~min}$ (12 aliquots per animal). After $1 \mathrm{~min}, 10 \mu \mathrm{L}$ graded PAF solution $\left(10^{-5}-10^{-10} \mathrm{~mol} \cdot \mathrm{L}^{-1}\right)$ were added and the aggregation response was recorded for each concentration with a dual channel chronologue aggregometer with interface and software (Corp.-model 490-aggro/link software for Windows).

Inhibitory effects of SR 27417 were determined by using the dose-response curves of PAF on platelet aggregation. One minute before PAF, $10 \mu \mathrm{L}$ of SR 27417 at thirteen different concentrations $(0.1,0.5$,
$1,2,5,10,15,20,50,100,200,300$, $400 \mathrm{nM}$ ) were added in the cuvette. Results were expressed as the maximal slope of aggregation $\left(\% \cdot \mathrm{min}^{-1}\right)[2]$. The agro/link software automatically calculates the maximum slope (in percent of scale per minute) of the aggregation curve.

\subsection{Calculation of the $\mathrm{pA}_{2}$ value related to SR 27417}

The $\mathrm{pA}_{2}$ is defined as the negative logarithm to base 10 of the molar concentration of an antagonistic drug which requires the doubling $\left(=\mathrm{pA}_{2}\right)$ of the concentration of an agonistic drug in order to produce the same effect. In the present work, the $\mathrm{pA}_{2}$ value related to SR 27417 was calculated taking into account the change in the concentration of PAF inducing a $50 \%$ effect of the maximum effect $\left(\mathrm{ED}_{50}\right)$ measured for each test from the dose-response curve. The $\mathrm{pA}_{2}$ value for SR 27417 using the calves' platelets in PRP was determined from a Schild plot [26, 34] and analysed as described in [2].

\subsection{Statistical analysis}

The mean values \pm standard error of the mean (SEM) at the various concentrations of drug (SR 27417) were compared with control values by a nonparametric Wilcoxon ranks-test. $p$-values $\leq 0.01$ and $\leq 0.05$ were chosen to indicate a significant difference [28].

\section{RESULTS}

The values of the maximal slope of aggregation $(\% / \mathrm{min})$ obtained in the absence (control) and in the presence of increasing concentrations of SR 27417 for PAFinduced aggregation of calf platelets in PRP are given in Figure 1.

As shown by Figure 1, in vitro and Table I, PAF-induced calf platelet aggregation was dose-dependently inhibited by 


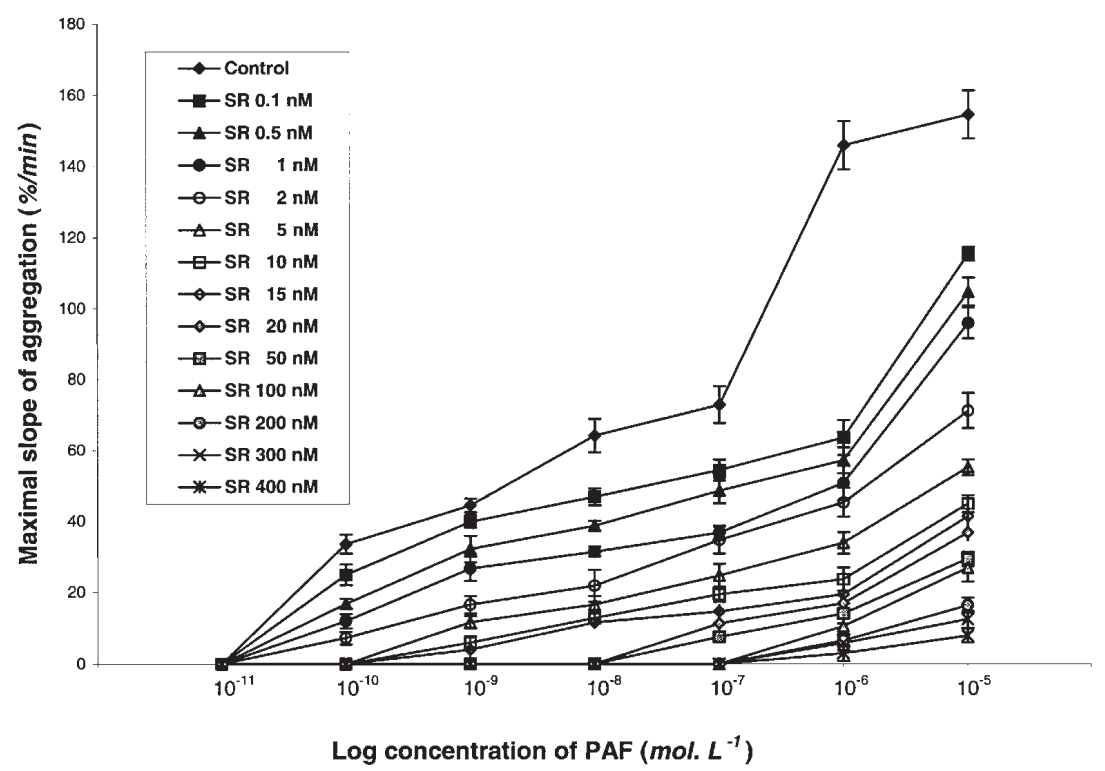

Figure 1. Concentration response curves for PAF-induced aggregation of calve platelets in PRP in the absence and in the presence of increasing concentrations of SR 27417. Values are Means \pm SEM $(\mathrm{n}=7)$ of the maximal slope of aggregation $\left(\% \cdot \mathrm{min}^{-1}\right)$.

SR 27417 pretreatment. In the presence of SR 27417, the maximal slope of aggregation induced by low and high concentrations of PAF (for the seven calves) were significantly different from the control values obtained without antagonist (at $p \leq 0.05$ and $p \leq 0.01$ respectively).

In the presence of all the different concentrations of SR 27417, the concentrationresponse curves of PAF on platelet aggregation were inhibited. The parallel shifts of the dose-response curve to the right indicated competitive antagonism. The $\mathrm{pA}_{2}$ value for SR 27417 measured over a range of SR 27417 concentrations of $0.1-10 \mathrm{nM}$, and taking into account mean values was $10.46 \pm 2.36 \mathrm{~mol} \cdot \mathrm{L}^{-1}$. The mean Schild regression was linear and had a slope not significantly different $(p<0.05)$ from unity $(0.35 \pm 0.09)$.

\section{DISCUSSION}

Our results showed for the first time that SR 27417 inhibits PAF-induced platelet aggregation in an in vitro model using calf blood.

The control values of maximal slope of aggregation support the previous results observed [2-4], showing that increasing concentrations of PAF can induce reversible and irreversible platelet aggregation in calves.

The present study showed that SR 27417 dose-dependently inhibits bovine platelet aggregation induced by both low and high concentrations of PAF. The parallel shifts of the dose-response curve to the right indicated competitive antagonism. These results were comparable with those obtained with washed rabbit platelets [2, 21, 23], in spite of the use of different methods for the processing of platelets (washed or unwashed).

Evidence has been demonstrated that PAF is intimately involved in the etiology of a variety of disorders including septic shock, anaphylaxis, thrombosis, hypotension, vasoconstriction, increased pulmonary artery pressure, increased pulmonary vascular resistance, induction of pulmonary oedema, 
asthma and allergy $[1,7,11,14,16,18,24$, $25,27,33,37-39]$. In addition, PAF infusion induces moderate thrombocytopenia in calves [4].

Therefore, the development of a specific PAF receptor antagonist could offer a rational and novel therapeutic approach for these diseases. SR 27417 has an inhibitory effect in vitro on the PAF induced aggregation of rabbit and human platelets and on the oxidative burst of guinea pig peritoneal macrophages $[21,23]$. This potency was not only expressed in vitro, but also by the ability of SR 27417, in vivo, to inhibit PAF-induced responses in mice and guinea pigs [6]. In fact, this inhibition was noticeable by an extremely long duration of activity. As already reported for other PAF antagonists in vivo models, SR 27417 was about 120 times more potent than WEB 2086 in inhibiting PAF-induced oedema formation in rabbit skin [22]. These results confirm data from other sources [20], showing that SR 27417 is one of the most potent PAF receptor antagonists.

In addition, when compared with the triazolothienodiazepine WEB 2086, SR 27417 was 70 times more potent against PAFinduced aggregation of rabbit and human platelets, respectively [22]. The present in vitro experiment, however, demonstrated that SR $27417\left(\mathrm{pA}_{2}=10.46\right)$ was 37 times more potent in $\mathrm{PAF}$-induced aggregation of bovine platelets than WEB $2086\left(\mathrm{pA}_{2}=\right.$ 7.61) [2]. Since the mean of SR 27417 Schild regression was linear and had a slope not significantly different from unity, these data satisfied the condition for competitive antagonism. The SR 27417 has been shown to be a highly potent, specific and competitive PAF receptor antagonist by its inhibitory results either in vitro or in vivo $[21,22]$.

In conclusion, these results showed that addition of SR 27417 to bovine platelets in vitro very effectively inhibits PAFinduced platelet aggregation in this species and suggests that SR 27417 may be a useful experimental drug with which to investigate the role of PAF in several bovine diseases.

\section{REFERENCES}

[1] Argiolas L., Fabi F., Del Basso P., Mechanisms of pulmonary vasoconstriction and bronchoconstriction produced by PAF in the guinea-pig: role of platelets and cyclo-oxygenase metabolites, $\mathrm{Br}$. J. Pharmacol. 114 (1995) 203-209.

[2] Bastos da Silva M., Herion F., Raskinet R., David J-L., Gustin P., Dessy C., Lekeux P., Inhibition of PAF-induced platelet aggregation by WEB 2086 in vitro, an antagonist to the receptor for plateletactivating factor, in bovine, J. Vet. Med. A 43 (1996) 399-413.

[3] Bastos da Silva M., Gustin P., Herion F., Raskinet R. David J.-L., Gougnard T., Plomteux G., Desmecht D., Lekeux P., The effect of intravenous administration of WEB 2086 on PAFinduced platelet aggregation in health Friesian calves, Vet. Res. Commun. 21 (1997) 521-531.

[4] Bastos da Silva M., Dessy C., David J.-L., Lekeux P., Morphological alterations of blood platelets induced by platelet activating factor (PAF) and partial inhibition by ketiprofen in calves, Vet. Res. 28 (1997) 489-502.

[5] Bastos da Silva M., Gustin P., Herion F., David J.-L., Van De Weerdt M.L., Lekeux P., Effect of ketoprofen on PAF-induced bovine platelet aggregation, Vet. J. 155 (1998) 201-203.

[6] Bernart A., Herbert J.-M., Salel V., Lespy L., Maffrand J.P., Protective effect of SR 27417, a novel PAF antagonist, on PAF or endotoxininduced hypotension in the rat and the guineapig, J. Lipid. Mediators 51 (1992) 41-48.

[7] Bernart A., Herbert J.-M., Effect of various drugs on adriamycin-enhanced venous thrombosis in the rat: importance of PAF, Thromb. Res. 75 (1994) 91-97.

[8] Bondy G.S., Gentry P.A., Characterization of the normal bovine platelet aggregation response, Comp. Biochem. Physiol. C92 (1989) 67-72.

[9] Born G.V.R., Quantitative investigations into the aggregation of blood platelets, J. Physiol. (Lond.) 162 (1962) 67.

[10] Braquet P., Godfroid J.J., PAF-acether binding sites: 2 designers of specific antagonists, Trends Pharmacol. Sci. 7 (1986) 397-403.

[11] Braquet P., Touqui L., Shen T.Y., Vargaftig, B.B., Perspectives in platelet-activating factor research, Pharmacol. Rev. 39 (1987) 97-145.

[12] Casals-Stenzel J., Weber K.H., Triazolodiazepines: dissociation of their PAF (plateletactivating factor) antagonistc and CNS activity, Br. J. Pharmacol. 90 (1987) 139-146. 
[13] Chan W.P., Levy J.V., Effects of antiplatelet agents on platelet aggregation induced by plateletactivating factor (PAF) in human whole blood, Prostaglandins 42 (1991) 337-342.

[14] Cheryk L.A., Hooper-Mcgrevy H.E., Gentry P.A., Alterations in bovine platelet function and acute phase proteins induced by Pasteurella haemolytica $\mathrm{A}_{1}$, Can. J. Vet. Res. 62 (1998) 1-8.

[15] Chignard M., Le Couedic J.P., Tencé M., Vargaftig B.B., Benveniste J., The role of plateletactivating factor in platelet aggregation, Nature (London) 279 (1979) 799-800

[16] Collins L.C., Roberts A.M., Effects of plateletactivating factor on arteriolar and venular tone in rat trachea, Microvasc. Res. 53 (1997) 63-72.

[17] Foster A.P., Cunningham F.M., Andrews M.J., Lees P., A comparison of the action of plateletactivating factor (PAF) antagonists WEB 2170 and 2086 in the horse, J. Vet. Pharmacol. Ther. 16 (1993) 477-487.

[18] Handley D.A., Development and therapeutic indications for PAF receptor antagonist, Drugs Future 13 (1988) 137-152.

[19] Heath M.F., Evans R.J., Hayes L.J., Dextran-70 inhibits equine platelet aggregation induced by PAF but not by other agonists, Equine Vet. J. 30 (1998) 408-411.

[20] Hellewell P.G., Williams T.J., Antagonism of PAF-induced oedema formation in rabbit skin: a comparison of different agonists, Br. J. Pharmacol. 97 (1989) 171.

[21] Herbert J.M., Bernart A., Valette G., Gigo V., Lale A., Laplace M.C., Lespy L., Savi P., Maffrand J.P., Le Fur G., Biochemical and pharmacological activities of SR 27417, a highly potent, long acting platelet activating factor receptor antagonist, J. Pharmacol. Exp. Therapy 259 (1991) 44-51.

[22] Herbert J.M., Valette G., Bernart A., Savi P., Maffrand J.P., Le Fur G., SR 27417, a highly potent, selective and long-acting antagonist of the PAF receptor, Drugs Future 17 (1992) 10111018

[23] Herbert J.M., Laplace M.C., Maffrand J.P., Bindind of [ H]SR 27417, a novel platelet-activating factor (PAF) receptor antagonist, to rabbit and human platelets and polymorphonuclear leukocytes, Biochem. Pharmacol. 45 (1993) 5158.

[24] Herbert J.M., Bernart A., Tibirica E., Effect of SR 27417, a novel PAF antagonist on antigeninduced hypotension in the rat, J. Lip. Mediators Cell Signal. 15 (1997) 115-123.

[25] Imai T., Adachi M., Horikoshi S., Sugeta A., Idaira K., Takahashi T., Tanaka Y., Relation of platelet activating factor induced airway hyperresponsiveness to thromboxane $\mathrm{A}_{2}$ and neutrophil in dogs, Arerugi 42 (1993) 1563-1568.
[26] Kenakin T.P., Pharmacological analysis of drug receptor interaction, Raven, New York, 1987, pp. 210-217.

[27] Lekeux P., Gustin P., Desmecht D., Linden A., Thérapeutique des pathologies respiratoires aiguës des bovins, Ann. Méd. Vét. 135 (1991) 175-184.

[28] Leroy P., Farnir F., Méthodes Statistiques en Médecine Vétérinaire, Départment de Génétique, Faculté de Médecine Vétérinaire-Université de Liège, Belgique, 1998, pp. 251-257.

[29] Livio M., Vigano G., Morigi M., Ubiali A., Galbusera M., Remuzzi G., Rôle of platelet-activating factor in primary hemostasis, Am. J. Physiol. 254 (1988) 1218-1223.

[30] Oyekan A.O., Ablordeppey S.Y., The mechanisms of the antiaggregatory effects of cryptolepine: the role of cyclic adenosine monophosphate and cellular $\mathrm{Ca}_{2}{ }^{+}$, Genet. Pharmacol. 24 (1993) 461-469.

[31] Ponpidom M.M., Hwang S.B., Doebber T.W., Acton J.J., Alberts A.W., Biftu T., Brooker D.R., Bugianesi R.L. Chabala J.C., Gamble N.L., Graham D.W, Wu M.S., 士-trans-2-(3-Methoxy-5methylsulfonyl-4-propoxyphenyl)-5-(3-,4,5trimethoxyphenyl) tetra-hydrofuran (L-659-989), a novel, potent PAF receptor antagonist, Biochem. Biophys. Res. Comm. 150 (1988) 1213-1220.

[32] Prescott S.M., Stafforini D.M., Zimmerman G.A., Mcintyre T.M., The natural history of PAF: from physiological regulator to pathological mediator, in: Proceedings 5th International Congress on Platelet-Activating Factor and Related Lipid Mediators, Berlin, 1995, p. 2.

[33] Sagara H., Makino S., Fukuda T., PAF receptor antagonist in asthma therapy, Nippon Rinsho 54 (1996) 3056-3061.

[34] Schorderet M., Pharmacologie des concepts fondamentaux aux applications thérapeutiques, Frison-Roché, Paris, Ed. Slaktine, 1988, pp. 3-19

[35] Schumacher W.A., Steinbacher T.E., Heran C.L., Megill J.R., Durham S.K., Effects of antithrombotic drugs in a rat model of aspirin-insensitive arterial thrombosis, Thromb. Haem. 69 (1993) 509-514.

[36] Soloviev A.I., Braquet P., Platelet-activating factor - A potent endogenous mediator responsible for coronary vasospasm, News Physiol. Sci. (NIPS) 7 (1992) 166-172.

[37] Terashita Z.I., Imura Y., Nishikawa K., Inhibition by CV-3988 of the binding of [_H]-platelet activating factor (PAF) to the platelets, Biochem. Pharmacol. 34 (1985) 1491-1495.

[38] Van De Weerdt M.-L., Desmecht D., Lekeux P., Effect of platelet-activating factor on bovine pulmonary function, Vet. Rec. 16 (1997) 168-172.

[39] Vargaftig B.B., PAF a mediator in search of a disease, Clin. Rev. Allergy 12 (1994) 419-421. 